\title{
Fuel Cells: The Next Evolution
}

\section{Robert W. Lashway, Guest Editor}

\begin{abstract}
The articles in this issue of MRS Bulletin highlight the enormous potential of fuel cells for generating electricity using multiple fuels and crossing a wide range of applications. Fuel cells convert chemical energy directly into electrical energy, and as a powergeneration module, they can be viewed as a continuously operating battery. They take in air (or pure oxygen, for aerospace or undersea applications) and hydrocarbon or hydrogen fuel to produce direct current at various outputs. The electrical output can be converted and then connected to motors to generate much cleaner and more fuelefficient power than is possible from internal combustion engines, even when combined with electrical generators in today's hybrid engines. The commercialization of these fuel cell technologies is contingent upon additional advances in materials science that will suit the aggressive electrochemical environment of fuel cells (i.e., both reducing and oxidizing) and provide ionic and electrical conductance for thousands of hours of operation.
\end{abstract}

Keywords: ceramics, electrochemistry, fuel cells, molten carbonates, polymer electrolyte membranes, solid-oxide membranes.

\section{Introduction}

The invention of the solid-state transistor in the late 1940s led to a new age. The technological evolution of microprocessing, from simple watches and calculators to personal computing and wireless communications, has also been responsible for the progress in micro-manufacturing (e.g., microelectromechanical systems, cleanroom technology, and other advances in materials science). The solid-state fuel cell has the potential to generate another new age, in the areas of distributed energy, a cleaner environment, and more efficient use of the earth's natural resources. The need for cleaner energy-producing equipment is becoming a commercial necessity and will continue to grow in importance as the demand for oil outpaces production capacity in the next decade. ${ }^{1}$ Advancements in materials science as well as in microprocessing will be needed to ensure the chemical and mechanical long-term reliability of the thin electrolyte membranes used in most fuel cell technologies.

\section{What Is a Fuel Cell?}

A fuel cell is an electrochemical device, like a battery, that is continuously fueled (e.g., by fuel plus oxygen from the air). Each cell consists of an electrolyte (a conducting ionic membrane) with an inte- grated porous anode and cathode. Hydrogen and/or hydrocarbon fuels react at the anode side, while oxygen (from air) reacts at the cathode side. The output is electrical energy in the form of direct current. When hydrogen is used as the fuel, the final exhaust product is simple water (i.e., zero oxides of sulfur and nitrogen, zero hydrocarbon soot, and zero carbon dioxide or monoxide).

A fuel cell assembly is composed of multiple cells that are generally placed in stacks and electrically connected in series. The electrolyte conducts the ions, but must also retain a hermetic seal in order to separate the fuel flow at the anode side from the air/oxygen flow at the cathode side. Both electrodes are integrated onto the electrolyte membrane and must contain open porosity for fuel and air-flow reactions with the input gases, ions, and output electrons.

The fuel cell assembly depends upon the type of electrolyte medium used, but generally is composed of the following:

- Electrolyte membrane (with high ionic conductivity and retained hermetic seal), - Anode (fuel side of the electrode with a porous composite structure containing ion-conducting media, high surface areas for reaction, and catalysts lodged at the triple points where the reaction occurs among the gases, ions, and electrons),

- Cathode (air side of the electrode, with the same properties as the anode but in an oxidizing environment), and

- Separator and gas-flow structures (supplying air and fuel flow to the electrodes and also separating each cell hermetically while conducting electrons).

Each of these components will be described for the fuel cell types discussed in the following articles. The common denominator for the commercial success of fuel cells depends upon future research, especially in materials science, because the applications require long operational lifetimes in aggressive environments (e.g., >5 years in a reducing plus oxidizing environment).

Nanotechnology will play a great role in advancing the life and efficiency of fuel cell systems. Polymer electrolyte membrane (PEM) fuel cells, also referred to as proton-electrolyte membrane or protonexchange membrane fuel cells, currently use platinum catalysts, and the amount of $\mathrm{Pt}$ must be minimized (i.e., $<0.2 \mathrm{mg} / \mathrm{W}$ ). Nanotechnology and advances in surface chemistry will lower production costs and improve reactivity rates (vital for higher power output over longer operating times) by increasing the surface areas at the triple points of the electrode. Each fuel cell technology is undergoing a scientific evolution, especially in the electrolyte, cathode, and anode chemistries. The rate of progress in solid-oxide fuel cell (SOFC) technology is demonstrated in the fact that there have already been at least three generations as of 2004 . $^{2}$

\section{Fuel Cell Types and Technologies}

Today, there are many types of fuel cell technologies, but polymer electrolyte membrane fuel cells (PEMFCs) and solidoxide fuel cells (SOFCs) are considered the primary candidates, based on the billions of dollars per year spent in worldwide research and development (R\&D). These two technologies have the lowest manufacturing costs, as shown by Department of Energy (DOE) studies and by large energy equipment manufacturers (i.e., General Electric, Siemens Westinghouse, Toyota, Ballard, and others). Table I illustrates the major features, operating conditions, fuels, and other key parameters for several fuel cell technologies.

Each fuel cell type represents different technologies requiring unique materials solutions. The differences range from the electrolyte chemistry and operating temperatures (i.e., from $80^{\circ} \mathrm{C}$ for PEMFCs to $800^{\circ} \mathrm{C}$ for zirconium oxide SOFCs), to the chemistry and microstructure of the elec- 
Table I: Comparison of Fuel Cell Types.

\begin{tabular}{|c|c|c|c|c|}
\hline \multirow[t]{3}{*}{ Parameters } & \multicolumn{4}{|c|}{ Primary Fuel Cell Types } \\
\hline & Polymer Electrolyte & Solid-Oxide & Molten Carbonate & Phosphoric Acid \\
\hline & (PEMFC) & (SOFC) & (MCFC) & (PAFC) \\
\hline Conducting lon & $\mathrm{H}^{+}$ & $\mathrm{O}^{2-}$ & $\mathrm{CO}_{3}^{2-}$ & $\mathrm{H}^{+}$ \\
\hline Operating Temperature & $90^{\circ} \mathrm{C}$ & $800^{\circ} \mathrm{C}$ & $650^{\circ} \mathrm{C}$ & $100^{\circ} \mathrm{C}$ \\
\hline Fuel & pure $\mathrm{H}_{2}$ & $\mathrm{CH}_{4}, \mathrm{CO}$ (both or separate) & $\mathrm{CH}_{4}, \mathrm{CO}$ & pure $\mathrm{H}_{2}$ \\
\hline Efficiency & $35 \%$ & $45 \%$ & $50 \%$ & $40 \%$ \\
\hline Power Range & up to $150 \mathrm{~kW}$ & $5-250 \mathrm{~kW}$ & megawatt & $5-250 \mathrm{~kW}$ \\
\hline Applications & $\begin{array}{l}\text { transportation, } \\
\text { mobile/small devices } \\
\text { (PCs, laptops), } \\
\text { telecommunications }\end{array}$ & $\begin{array}{l}\text { distributed generation, } \\
\text { marine }\end{array}$ & $\begin{array}{l}\text { biomass, marine, } \\
\text { water utilities }\end{array}$ & $\begin{array}{l}\text { distributed } \\
\text { generation, } \\
\text { backup } \\
\text { generation }\end{array}$ \\
\hline
\end{tabular}

trode integrated onto the electrolyte surfaces (front and back). Likewise, the gasflow and separator structures and chemistries also must match the electrolyte temperature and environment (both chemically and mechanically, including such parameters as thermal expansion). The eventual scientific solutions for each of the different fuel cell components, electrolytes, electrodes, and separation/gas-flow structures are critical for current and future R\&D. Each fuel cell technology encounters a very aggressive environment, and long-term reliability significantly affects the economics and commercialization of the technology (all of which are tied to the materials' life in its hostile environment.).

\section{Fuel Cell Research and Development: Solutions for the Future}

This issue of MRS Bulletin will focus on three fuel cell types:

- Polymer electrolyte membrane fuel cells,

- Solid-oxide membrane fuel cells and

SOFC interconnects, and

- Molten carbonate fuel cell (MCFC) technology.

Other technologies not covered here include phosphoric acid and zinc-air fuel cells.

This collection of articles presents a tutorial approach for the general technical audience. In addition to discussions of the key electrolytes, aspects of the cell and system engineering are treated (primarily in the case of SOFC interconnects and molten carbonate fuel cells). These include important design features as well as manufacturing and economic data that are vital to the long-term commercial success of the technology. Many of these engineering examples illustrate the need for advanced materials science (i.e., somewhere in the SOFC cell structure, there will be a point that will have to accommodate both reduction and oxidation as the partial pressure of oxygen changes). Since fuel cells must perform reliably over thousands of hours, the materials must function continuously under the differing operating conditions.

PEMFCs are one of the largest research areas in fuel cell development. The U.S. automotive industry is advancing fuel cell research using hydrogen, as part of DOE's promotion of a hydrogen economy. Other major industrial nations have similar government-sponsored programs in place. The key drivers in the U.S. are the environment (i.e., concern over the carbon dioxide greenhouse effect) and reducing the country's reliance on imported oil. In addition, restrictions on emissions of nitrogen oxides and sulfur oxides (especially starting in 2007, when new federal standards take effect), as well as on particulates from carbon sources, will make fuel cells an attractive alternative, due to their lower operating temperatures and lower emissions as compared with internal combustion engines.

The current interest in hybrid engines (gas/diesel engines plus generators with electric motors for automotive power) is a forerunner to all-solid-state power in the form of fuel cells. Fuel cell technology is cleaner, quieter, and more fuel-efficient than internal combustion engines, even hybrids. PEMFC technology is also attracting heavy investment in research for lower-power applications as a replacement for batteries. Methanol is the fuel used, and tests are under way with laptop PCs using direct methanol fuel cells. The key benefits of fuel cells over batteries are longer life and lighter weight, which are especially important in mobile applications. Fuel cells offer energy densities that are much higher than those of batteries, which is a notable advantage when hydrogen is used as the fuel.

Both the SOFC and the MCFC are directed at stationary, distributed power generation for buildings and industry. These applications require long lifetimes; the DOE has set $40,000 \mathrm{~h}$ as a minimum operating-life goal for stationary fuel cells under their SECA (Solid-State Energy Conversion Alliance) program. ${ }^{3}$

The most important challenge in fuel cell research is providing sustainable high power density at a reasonable cost. Power density is generally measured by the power output of the fuel cell membrane area (e.g., watts per square centimeter) and power loss, also referred to as power degradation over time, given as the loss in percent per $1000 \mathrm{~h}$ of operation. Cost is generally discussed as the price per kilowatt of power for the fuel cell system. The articles in this issue will refer to these criteria and others to describe many of the $R \& D$ efforts in this technology area.

\section{Overview by Article}

The first article, by Rajendran, discusses polymer electrolyte technology. Rajendran's focus is on hydrogen applications, but this discussion is also relevant to membranes for direct methanol use. One of the major R\&D areas for PEM fuel cells is the management of water throughout the fuel cell operation; this is particularly important in cold temperatures (the system must be designed to prevent freezing) and when the system is idle. This article 
will touch on the development of new technologies to alleviate water management problems. The discussion will also touch on polymer chemistry and microstructures to attain sustainable high power densities. Sulfonated fluoropolymers have been the workhorse of PEM fuel cells; however, new compositions, such as sulfonating poly(ether ether ketone) $(\mathrm{PEEK}),{ }^{4}$ are in the testing stage. In addition, research is under way to develop reinforced membranes to strengthen and increase fuel cell tolerance to hydration. These membranes could include composites of PEM in a SOFC matrix.

The article by Yokokawa and colleagues covers solid-oxide electrolytes for SOFCs. The most common materials in current use are zirconia-based membranes doped with yttria or scandia in thin structures (i.e., electrode-supported, to keep the thickness of the membranes under $25 \mu \mathrm{m}$ so as to reduce cell resistance). The dopant chemistry and concentration dictate the operating temperature and ionic conductance (based on optimum ionic conductance of oxide ions). Another approach under investigation for solid-oxide ion conduction is lanthanum gallate doped with strontium, magnesium, and other elements, which operate at lower temperatures than zirconia-based electrolytes $\left(650^{\circ} \mathrm{C}\right.$ versus $800^{\circ} \mathrm{C}$, respectively). The goal is to maintain a higher ionic conductance at lower operating temperature; however, the tensile strength of lanthanum gallate is less than half that of zirconia. Therefore, lanthanum gallate research includes a search for reinforcements to increase strength. The article also discusses some of the electrode chemistries and barrier layers such as gadolinia ceria.

Japan, Europe, and the United States are investing heavily in SOFC technology for distributed power generation and auxiliary power units (APUs). Because of the higher operating temperatures of SOFCs, they are more difficult to employ in transient applications with numerous on-off cycles than PEM technology. As an example, PEMFCs are expected to be the primary power source for transportation applications, while SOFCs are being de- veloped for stationary applications. There are some APU applications within vehicles where SOFCs might be applicable, such as in trucks for quiet, overnight "hotel" power usage with the main engine off.

Although the articles in this issue cannot cover all the assembly technologies within each fuel cell type, one unique SOFC assembly technology will be discussed. SOFCs require materials that can endure an oxidizing/reducing environment at a much higher operating temperature than PEMFCs. In addition, the separator and gas-flow materials must continually conduct electrons, not ions, while providing matched coefficients of thermal expansion with the electrolyte.

There are three current approaches to SOFC interconnection being developed:

- Metal interconnect structures that oxidize on the surface to provide electrical conductivity with the addition of dopants or deposited coatings;

- Electrically conducting ceramic perovskite-type materials; and

- Nonconducting ceramic structures with electrically conducting holes, or vias, as they are commonly referred to in the electronics packaging industry.

The last approach is unique in that the fuel cells can contain conductive interconnects "embedded" in the ceramic interconnect structure, thereby extending the corrosion resistance of the conducting media in the vias and planar lines. This approach is seeing renewed interest because the metals in current use employ chromium. In contrast to other alloys and dopants, chromium forms an electrically conductive layer (germane to the cathode/oxidizing side of the cell). The problem is that chromium migrates to the electrode/electrolyte interfaces and causes irreversible increases in resistance that degrade the power density of the system. ${ }^{5}$

The third article in this issue, by Morris et al., discusses nonconducting ceramic via interconnect technology. This approach allows the cell to be constructed with the optimum thermal expansion match to the electrolyte. The authors will describe the chemistry and structures of this technology as well as the ability to manufacture these fuel cells at a lower cost through multilayer cosintering technology (as is currently in use for highvolume manufacturing of electronics and ceramic multilayer capacitors).

The final article, by Farooque et al., will discuss the molten carbonate fuel cell. The MCFC is in the commercialization phase and is particularly attractive for use with biomass or utility plant effluents. The article will describe design/structures, application technologies, cell chemistries, and the basic materials science needs for a sustainable system. The discussion will include design and manufacturing, which are important to achieving the reliability required.

\section{Conclusion}

Fuel cells offer the advantages of cleaner, quieter power generation while decreasing the use of natural resources. It is envisioned that all fuel cell types listed in Table I will find multiple applications, and their use will vary by application. The internal combustion engine combined with electrical generation cannot compare with the fuel cell for electrical conversion efficiency. In addition, fuel cells offer much higher specific energy densities than batteries. The key to the future success of the fuel cell is achieving higher sustainable energy densities at a competitive cost relative to the internal combustion engine, taking into consideration environmental impacts and the increasing cost of oil.

\section{References}

1. T. Appenzeller, National Geographic (June 2004) p. 80.

2. S. Harris, The Fuel Cell Review (June/July 2004) p. 31.

3. G. McVay, U.S. Dept. of Energy Report on Solid State Conversion Alliance (SECA) (U.S. Department of Energy, Washington, D.C., 1999).

4. M. Doyle and G. Rajendran, in Handbook of Fuel Cells: Fundamentals, Technology, and Applications, Vol. 3, Part 3, edited by W. Vielstich, A. Lamm, and H. Gasteiger (John Wiley \& Sons, Hoboken, N.J., 2003) p. 351.

5. K. Hilpert, in Handbook of Fuel Cells: Fundamentals, Technology, and Applications (John Wiley \& Sons, Hoboken, N.J., 2003) p. 1037.

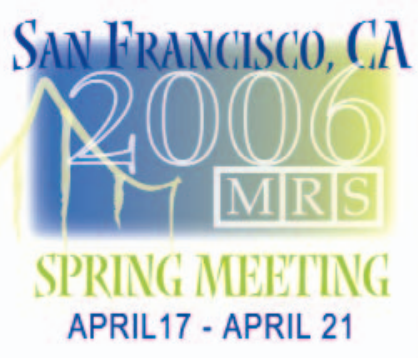


Robert W. Lashway, Guest Editor for this issue of MRS Bulletin, consults in the field of renewable, clean energy systems and advanced materials, including major work in solidoxide fuel cells. He holds a BS degree in chemical engineering from the University of Cincinnati. He went on to work at Dow Chemical-Union Carbide Corp. from 1970 to 1980 . He then worked for BP-Standard Oil of Ohio from 1980 to 1997; he was a general manager of advanced materials for his last five years there. In 1997, Lashway joined Advanced Refractory Technology Inc. (ART, purchased by Tyco in 2001) as program manager for a $\$ 20$ million TACOM contract. He was promoted in 2000 to vice president of marketing and business development and a corporate officer. Since mid-2001, he has worked as an energy consultant.

Lashway has published more than 15 technical papers and holds two U.S. patents. He is a member of the Materials Research Society and the U.S. International Coalition.

Lashway can be reached by e-mail at rlashway@cox.net.

Eric A. Barringer has been the technical director of SOFCo-EFS Holdings LLC (Alliance, Ohio) since 2004. He holds a $\mathrm{PhD}$ degree in ceramic science from the Massachusetts Institute of Technology (1983) and an MBA degree from Lynchburg College (1996). After two years on the faculty at MIT, he co-founded Ceramics Process Systems Corp. in 1985 and assumed responsibility for the company's microelectronics

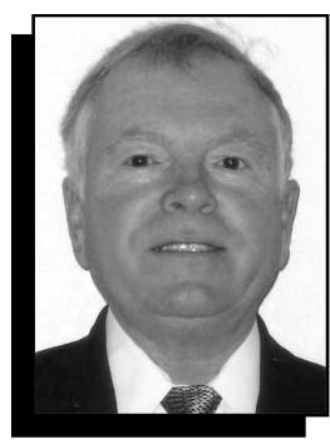

Robert W. Lashway

packaging technology and product development programs. In 1989, he joined the research and development division of McDermott Technology Inc., where he managed projects directed at the development of continuous fiber-reinforced composites and solid-oxide fuel cells. From 1994 to 1996, he served as a marketing manager for SOFCo, a limited liability partnership between McDermott and Ceramatec Inc. Barringer subsequently assumed overall responsibility for the corporate thermophotovoltaic power system program, including all technical and business activities. In 1998, Barringer was given responsibility for the development of the allceramic SOFC stack technology and served as program manager for the Affordable MultiLayer Ceramic Manufacturing for Power Systems (AMPS) program, co-funded by DOE. Following the formation of SOFCo-EFS in 2003, he assumed responsibility for the organization's marketing and business development activities.

Barringer can be reached by e-mail at eabarringer@sofco-efs. com.

Manuel E. Brito is a senior research scientist

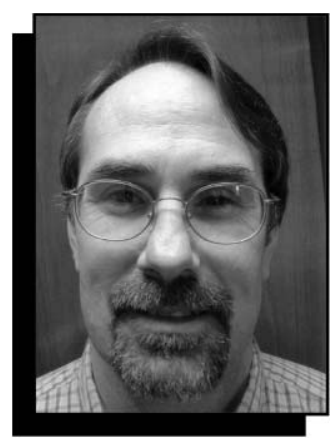

Eric A. Barringer

in the Energy Technology Research Institute at the National Institute of Advanced Industrial

Science and Technology (AIST) in Japan. He holds a BS degree (1982) from Universidad

Simon Bolivar,

Venezuela, and an MS degree (1986) from Nagaoka University of Technology, Japan, both in materials engineering. In 1989, he earned an engineering doctoral degree from Nagaoka University and joined its faculty for a short time. After a postdoctoral position at the National Institute for Inorganic Materials (NIRIN) in Tsukuba, Japan, he joined the National Industrial Research Institute of Nagoya at AIST in 1992. There, he was associated with the national project "Synergy Ceramics" until 2003.

His primary research field is the evaluation of interfaces and grain boundaries in novel materials via transmission electron microscopy and related analytical techniques. Currently, his research focuses on interfaces in solid-oxide fuel cells.

Brito is an author or co-author on more than 150 publications. He has been editor on three proceedings books and holds five international patents. He is also the chief editor of Advances

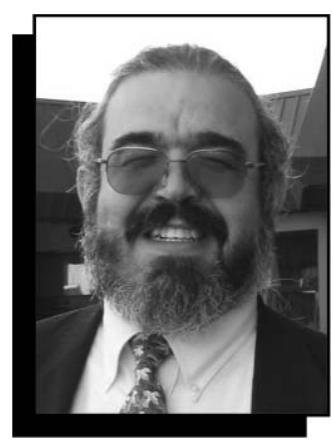

Manuel E. Brito

in Technology of Materials and Materials Processing (Australia) and has served as an associate editor for the Journal of the American Ceramic Society. Brito is a standing trustee of the Materials Research Society-Japan, as well as a member of the Materials Research Society, the American Ceramic Society, the Electrochemical Society, the Microscopy Society of America, and the

Japanese Electron

Microscopy Society.

Brito can be reached by e-mail at manuelbrito@aist.go.jp.

Mohammad Farooque is the senior vice president of Direct FuelCell technology at FuelCell Energy Inc. (FCE) in Danbury, Connecticut, leading carbonate fuel cell development activities. He holds a bachelor's degree in chemical engineering from the Bangladesh University of Engineering and Technology in Dhaka and a PhD degree from the University of Waterloo in Canada. He joined FCE in 1979.

Throughout his career, he has been closely involved in all aspects of fuel cell technology and product development and is considered an expert in carbonate fuel cell technology. He played a key role in the development of FCE's

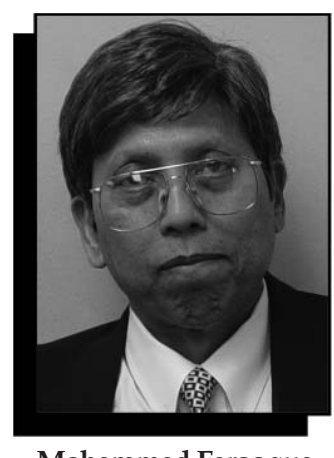

Mohammad Farooque

Direct FuelCell technology through the commercialization phase.

Farooque has authored approximately 100 publications on electrochemical systems and fuel cells, including two chapters in the Handbook of Fuel Cells: Fundamentals, Technology, and Applications, published in 2003 by John Wiley \& Sons. He holds 16 U.S. patents.

Farooque can be reached by e-mail at mfarooque@fce.com.

Teruhisa Horita is a senior research scientist in the fuel cell group at the Energy Technology Institute within the National Institute of Advanced Industrial Science and Technology (AIST) in Tsukuba, Japan. He holds a BS degree (1990) and a master's degree in engineering (1992) for mineralogy and materials science from Waseda University in Tokyo. In April 1992, he became a research scientist for the National Chemical Laboratory for Industry, later known as the National Institute of Materials and Chemical Research (NIMC) and now AIST. He received a PhD degree from Waseda University in 1998, followed by an Alexander von Humboldt fellowship (1998-2000) at the University of Karlsruhe in collaboration with Professor Ellen Ivers-Tiffee. 


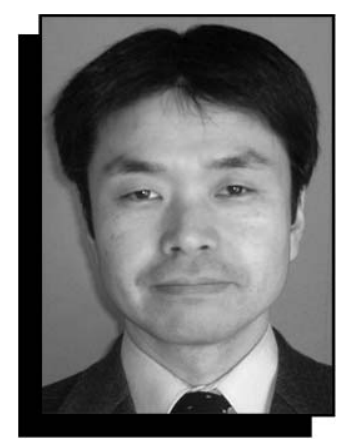

Teruhisa Horita

Horita's main research field is the analysis of ceramic interfaces of solid-oxide fuel cells. He developed a unique analytical method combining isotope labeling and secondary ion mass spectrometry for analyzing these interfaces. His work on the analysis of mass transport at the interfaces of SOFC materials was honored with the Oronzio De Nora Foundation Prize on Electrochemical Energy Conversion from the International Society of Electrochemistry (ISE) and the Richard M. Fulrath Award from the American Ceramic Society (2005).

Horita can be reached by e-mail at t.horita@ aist.go.jp.

Steven C. Kung received his BS degree in chemistry and his MS and $\mathrm{PhD}$ degrees in metallurgical engineering from the Ohio State University. Prior to and following his $\mathrm{PhD}$, he worked in several industries, including steel, glass, and energy. His expertise includes fireside corrosion, hightemperature electrochemistry, surface chemistry and reactions, and diffusion coatings. He has developed corrosion models that were incorporated into the EPRI boiler codes and are widely used to pre-

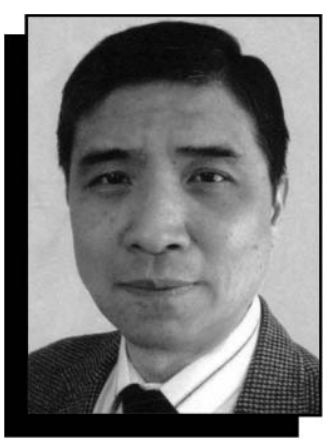

Steven C. Kung

dict the corrosion wastage of water walls in boilers exposed to mixed oxidizing/sulfidizing environments.

Kung has authored more than 60 refereed publications and formal reports and is the sole or lead inventor on six U.S. patents. Recently, he authored the chapter "Fireside Corrosion in Coal- and Oil-Fired Boilers" in the ASM Handbook, Volume 13B, Corrosion: Materials, scheduled to be published in late 2005.

Kung can be reached by e-mail at sckung@ sofco-efs.com.

Hans C. Maru is the executive vice president and chief technology officer at FuelCell Energy Inc. (FCE) in Danbury, Connecticut. He holds a BTech degree from the Indian Institute of Technology (1967) and a $\mathrm{PhD}$ degree from the Illinois Institute of Technology (1975), both in chemical engineering. Prior to joining FCE, Maru worked at the Institute of Gas Technology for eight years in the fields of fuel cells, electrolyzers, thermal energy storage, and hydrogen energy. He was previously the senior vice president at FCE, which he joined in 1977. Since then, he has assumed increasing responsibility for the direction and

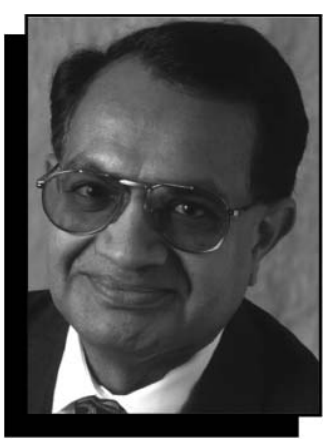

Hans C. Maru

management of a number of products, including design and development, product testing, staffing, contract negotiations, and planning.

Maru is an internationally recognized expert in the fuel cell generator field and has been granted 13 patents in this area. He has authored more than 150 publications, including chapters in two books, and he has edited four symposium proceeding volumes for fuel cells and batteries. He has also been awarded the 2003 High-Tech All-Star Award and the 2004 Francis T. Bacon Achievement Award.

Maru can be reached by e-mail at hmaru@ fce.com.

\section{Rodger W. McKain heads SOFCo-EFS} (Alliance, Ohio), a solidoxide fuel cell company aimed at advancing fuel cell and fuel processor technology and commercial products. $\mathrm{He}$ holds a BS degree in chemistry from the College of William and Mary and a PhD degree in chemistry from Case Western Reserve University. He was the vice president of research for BP America, as well as the head of central research at McDermott International, which wholly owns SOFCo-EFS, prior to his current position.

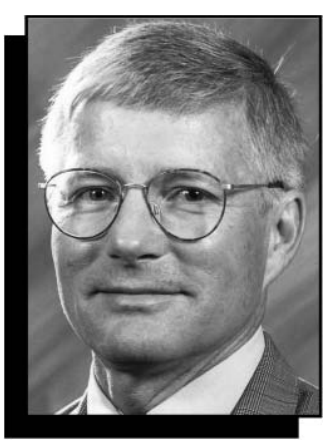

Rodger W. McKain

McKain is a past president of the Cleveland Engineering Society, chair of the Ohio Fuel Cell Coalition, and a member of the board of trustees of the Edison Welding Institute. He is also a member of the Sigma Xi Scientific Research Society, the American Association for the Advancement of Science, and the American Chemical Society.

McKain can be reached by e-mail at rwmckain@sofco-efs.com.

Thomas A. Morris serves various functions within SOFCo-EFS, including program manager for SOFCo's 1-2 kW fuel cell system being built under a program for the Ohio Department of Development, and team leader for prototype manufacturing of interconnects. $\mathrm{He}$ received his $\mathrm{BS}$ and MS degrees in mechanical engineering from West Virginia University in 1976 and 1979, respectively. In 1977, he joined the Research and Development Division of Babcock \& Wilcox Co. as a senior engineer, working on the development of fluidized bed combustion systems and low-NO $\mathrm{NO}_{x}$ burners. From 1989 to 1999 , he was manager of the Combustion Technology Section, overseeing work that supported Babcock \& Wilcox/ McDermott's commercial coal, oil, and gas burners and related combustion technologies. Thereafter, he transferred to McDermott's fuel cell group, where he managed SOFCo's internally funded fuel cell program.

Morris can be reached by e-mail at tamorris@ sofco-efs.com.

Raj G. Rajendran is a research associate at the DuPont Co., working in the materials science and engineering section of Central Research and Development. He received his $\mathrm{PhD}$ degree in chemistry in 1989 from the Indian Institute of Technology in Madras, India, where he studied the behavior of ionsolvent interactions and transport phenomena in mixed-solvent systems. He started his career as a research and development chemist in an auto electrical company in 1989 and moved to fuel cell research in 1990.

Afterward, he held a variety of positions in the alternative energy area, notably, in the development of polymer electrolyte lithium batteries and fuel cells. Since joining DuPont in 1995, he has been primarily involved in the development of new membranes and membrane/electrode assemblies for polymer electrolyte membrane fuel cells. He has contributed to many publications and presentations and recently co-authored the chapter "Perfluorinated Membranes" for the Handbook of Fuel Cells: Fundamentals, Technology, and Applications, published by John Wiley \& Sons (2003).

Rajendran can be reached by e-mail at 
raj.g.rajendran@usa. dupont.com.

Natsuko Sakai is a senior research scientist in the fuel cell group at the Energy Technology Research Institute within the National Institute of Advanced Industrial Science and Technology (AIST) in Tsukuba, Japan. Her primary interest is the transport properties of ions and electrons in complex metal oxides, which are correlated with the electrochemical properties or degradation behavior of materials.

Sakai graduated from the faculty of science at Kobe University in 1988 and then joined the National Chemical Laboratory for Industry. From January 1993 to July 1994, she was a research associate at the University of Oslo, under a scholarship from the Norwegian Research Council. She received a doctor of science degree from Kobe University in 1996.

She is a member of the international advisory committee for the 14th and 15th International Conferences on Solid State Ionics and was a trustee of the Electrochemical Society of Japan from 2001 to 2003.

Sakai can be reached by e-mail at n-sakai@ aist.go.jp.

Katsuhiko Yamaji is a research scientist in the fuel cell group at the Energy Technology Research Institute within the National Institute of Advanced Industrial Science and Technology
(AIST) in Tsukuba, Japan. Yamaji received his master's degree in materials engineering from Waseda University in 1994 before joining the National Institute for Materials and Chemical Research, which later became AIST. His primary interests are the electrical and electrochemical properties and processing of inorganic materials, with his current research focusing on solid-oxide fuel cell materials.

Yamaji can be reached by e-mail at k-yamaji@ aist.go.jp.

Harumi Yokokawa is a principal research scientist and fuel cell group leader at the Energy Technology Research Institute within the National Institute of Advanced Industrial Science and Technology (AIST) in Tsukuba, Japan. He received his doctor of nuclear engineering degree from the University of Tokyo in 1977 and then joined the National Chemical Laboratory for Industry (later known as the National Institute for Materials and Chemical Research, and currently as AIST). From 1978 to 1980, he was a research associate in the James Frank Institute at the University of Chicago and worked with Professor O.J. Kleppa on experimental thermo-chemistry. $\mathrm{He}$ also worked on the thermochemical water splitting process, an aluminum blast furnace, and solid-oxide fuel cells with Dr. M. Dokiya.

His research interests are in materials thermo-

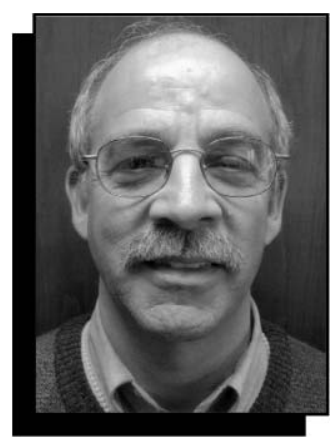

Thomas A. Morris

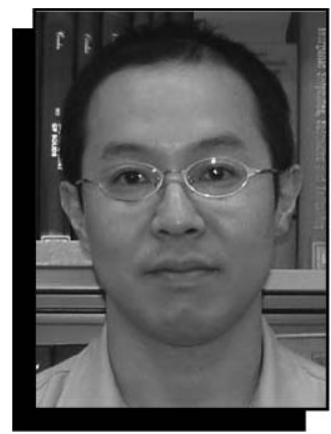

Katsuhiko Yamaji

dynamics and its applications to energy-

related materials issues, with his research currently focusing on solid-oxide fuel cell materials. He is a member of the group that developed the MALT (materials-oriented little thermodynamic)

database.

Yokokawa's work on the MALT database and its utilization in energyrelated fields has earned him awards from the Japan Information Center for Science and Technology and the Minister of the Agency for Science and Technology. In 2002, he was also honored with the Outstanding Achievement Award from the HighTemperature Materials Division of the Electrochemical Society. In

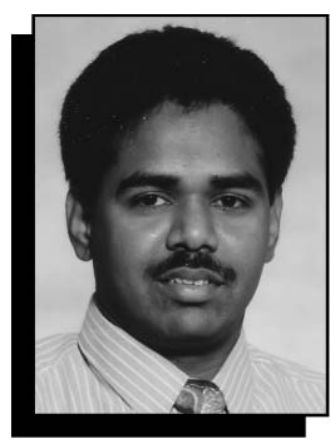

Raj G. Rajendran

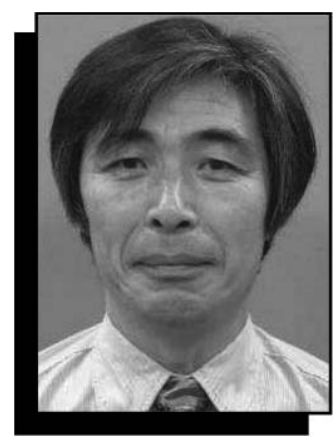

Harumi Yokokawa

2004, Yokokawa and his group were awarded the Christian Friedrich Schönbein Silver Medal from the European Solid-Oxide Fuel Cell Forum.

Yokokawa can be reached by e-mail at h-yokokawa@aist.go.jp.

Chao-Yi Yuh is the director of carbonate cell/stack development at FuelCell Energy Inc. (FCE) in Danbury, Connecticut. He holds a $\mathrm{PhD}$ degree in chemical engineering from the Illinois Institute of Technology (1985) and a BS degree in industrial chemistry from National Tsing-Hua University, Taiwan (1977). Prior to joining FCE in 1985, Yuh worked at the Institute of Gas Technology for four years, developing mathematical models

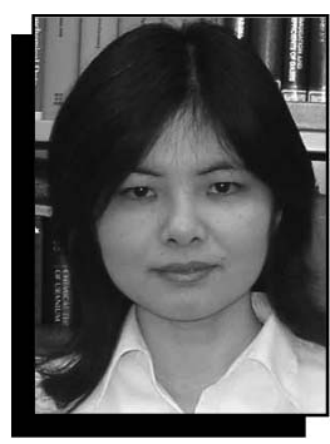

Natsuko Sakai

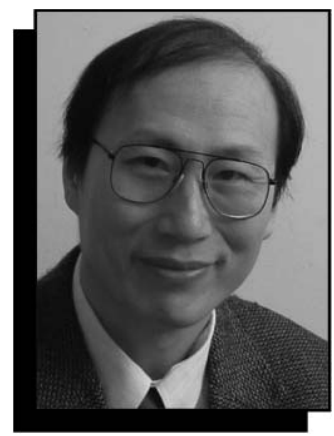

Chao-Yi Yuh

for porous electrodes. Before being appointed to his current position at FCE, he held the position of manager of materials development. Since then, he has assumed increasing responsibility for materials development, design, testing, and validation of fuel cell materials.

Yuh is an expert in the field of fuel cell materials and stack design and has been granted seven patents in this area, with several more applications submitted. He has authored more than 60 publications, including a chapter in the Handbook of Fuel Cells: Fundamentals, Technology, and Applications, published in 2003 by John Wiley \& Sons.

Yuh can be reached by e-mail at cyuh@ fce.com.

\section{New! www.mrs.org Coming Soon!}

